\title{
HISTORICAL CHANGES AND VEGETATION DEVELOPMENT AFTER INTENSIVE PEAT EXTRACTION IN THE LOWLAND MIRES OF SLOVAKIA
}

\author{
HORÁČKOVÁ, Šs. ${ }^{1,{ }^{*}}-$ PIŠÚt, P. ${ }^{1}-$ FALŤAN, V. ${ }^{1}-$ ChOVANEC, P. ${ }^{1}$ - PETROVIČ, F. ${ }^{3}$ \\ ${ }^{1}$ Department of Physical Geography and Geoecology, Faculty of Natural Sciences, Comenius \\ University in Bratislava, Ilkovičova 6, 84215 Bratislava 4, Slovakia \\ (e-mails:peter.pisut@uniba.sk,Vladimir.faltan@uniba.sk,chovanec39@uniba.sk) \\ ${ }^{2}$ Geographical Institute, Slovak Academy of Sciences \\ Štefánikova 49, 81473 Bratislava, Slovakia \\ ${ }^{3}$ Department of Ecology and Environmental Sciences, Faculty of Natural Sciences, Constantine \\ the Philosopher University in Nitra, Trieda A. Hlinku 1, 94974 Nitra, Slovakia \\ (e-mail:fpetrovic@ukf.sk) \\ *Corresponding author \\ e-mail: sarka.horackova@uniba.sk \\ (Received $10^{\text {th }}$ May 2018; accepted $5^{\text {th }}$ Jul 2018)
}

\begin{abstract}
Mires in the Danubian Lowland (Northern part of the Pannonian Basin) are typically overgrown with common alder (Alnus glutinosa). Similar stands at this location are unfortunately very rare, what is caused by continuous human intervention in landscape and its natural pattern from Early Holocene. Peatland degradation near Pusté Úl'any village started in the mid - eighteenth century, what is supported by historical maps. In the previous century a huge peat extraction took place at this specific mire. Despite these anthropogenic changes, there are still some remnants of natural habitats present, mostly dependant on ground water level. Methodology includes historical map's analysis, digital terrain model and vegetation cover mapping. Actual map of biotopes was completed for the current state of the vegetation cover acquaintance. Historical map's analysis revealed changes and development in the vegetation cover as well as the further relevant landscape changes in the mire during drainage system building. The first artificial drainage channel was built in the second half of the eighteenth century. Subsequently, dense system of the drainage channels was built near Továrniky settlement, continuing the drainage of this area for meadows, pastures and arable land acquisition. This wetland habitat was probably one of the largest mires in Slovakia during Holocene. Its area used to be markedly larger and its sedimentary basin presented much more important influence on landscape development. However, the historical sources revealed higher occurrence of common alder in the past, as well as typical xerothermic oak forest in this area. 27 biotopes were identified, from which 13 biotopes was purely human induced. Most of the area is currently abandoned for its own vegetation succession.
\end{abstract}

Keywords: biotope mapping, landuse, DTM, Pusté Úl'any, Danubian lowland

\section{Introduction}

Historical settlements on the Danubian Lowland, dated to Neolithic, means rather early human interference into natural vegetation cover in this area (Jamrichová et al., 2017; Opršal et al., 2016). Peatland and lowland mire prospection is a very important topic in the context of vegetation development research and climatic changes during Holocene (Petr et al., 2013; Szabó et al., 2016). Lowland mires present an important image about vegetation development in regional context as well (Petr et al., 2013). The important element in interpretation of vegetation development is sedimentary basin area of the mire (Sugita, 2007). Relevant factor in interpretation of vegetation development 
and landscape change is also human interventions and its influence on natural habitats. Archaeological records about Danubian lowland extends back to 7 500-7 600 cal years BP. (Jamrichová et al., 2017). Historical maps offer the cover of recent history, mostly to seventeenth or eighteenth century, however more precise and quantifiable (Pišút et al., 2007; Hrnčiarová et al., 2016). Changes of water-bounded communities reach and natural succesion process is visible precisely on the historical maps. Peatlands and mires were subject to severe mining for various purposes. Some of these areas were subject to permanent protection as protection areas. Unfortunately, as mire near village Pusté Úl'any was too large in its area, there were many efforts to drain this area and use it for agriculture. Similar large areas of peat accumulation in Danubian lowland are for example Súr in the north of the Danubian lowland near Little Carpathians Mts. (Petr et al., 2013) or Parížske močiare wetland mires in the southeast of Danubian lowland (Jamrichová et al., 2014, 2017), or Cerová-Lieskové on the Záhorská nížina lowland (East Wienna basin) (Kvaček et al., 2014).

In 1950s an intensive peat extraction took place in mire near Pusté Úl'any. Drainage canal systems are visible in landscape in the surrounding area as a part of protected bird area (Protected bird Area of Úl'any wetland, which is one of the 38 bird areas in Slovakia in the Natura 2000 network. The problem about this area is "no monitoring" (Kopecká, 2011, 2013). After peat extraction, degraded landscape with large ponds remained left for new vegetation succession (Kopecká, 2011, 2013; Hreško and Guldanová, 2012; Bubíková et al., 2016). So the aim of this article is to answer several inquiries about this area:

- What was the original area of the water-bounded communities of the mire near Pusté Úl'any?

- How was this area changing on the historical maps?

- In what manner human intervention was part of this changes and what is the actual condition of these biotopes now?

\section{Materials and methods}

\section{Research area}

Pusté Úl'any village is located in the west part of Slovakia between towns of Senec and Galanta. Mire is located between the villages Pusté Úl'any and Vel'ký Grob (Fig. 1). Currently the remains of the mire are visible mostly from orthophotomaps as peat extraction depressions. This mire is however tectonic interface between slightly curved Upland of Trnava loessic plain and Danubian plain (Mazúr and Lukniš, 1978). Geomorphologically it is a subassembly of Trnavsko-dubnická panva plain and Blatnianska priehlbina depression (INGEP, 2007; Maglay, 2005). In the residues of this Trnava looesic plain there are several depressions and depression valleys present including mire depression near Pusté Úl'any (INGEP, 2007; Maglay, 2005).

Geologically is the origin of the depressions scheme fixed to the complex of Trnava Upland, which is leaning towards south-east, where underground water is reaching the topsoil and produced organic sediments (peat). They are bounded to the local depressions with mires such as mire near Pusté Úl'any or Š́r near Little Carpathians Mts. (Maglay, 2005). Research area is restricted to the boundary connecting loose sediments and dominating alluvium. Mentioned alluvium is formed by grey and bright clays, silt, sand and gravels. Gravel sediments of the lower fluvial terraces of Váh River 
are located as well near Pusté Úl'any (Maglay, 2005). Research area is a depression part with gently sloping tectonic subsidence. Tectonic faults are usually directed NE-SW. Hydrogeologically it is district QN 050, named Quaternary of the Trnava Upland as a part of looesic sediments on fluvial terraces (Hrašna, 2002).

Nowadays, the hydrological surrounding is formed by Stoličný stream basin flowing into the Čierna voda river. Stoličný stream is $38.9 \mathrm{~km}$ long and it is flowing from the Little Carpathians Mts. Near wetland area in the Ul'anská mokrad' it is crossed by Čatajský stream near Vel'ký Grob village.

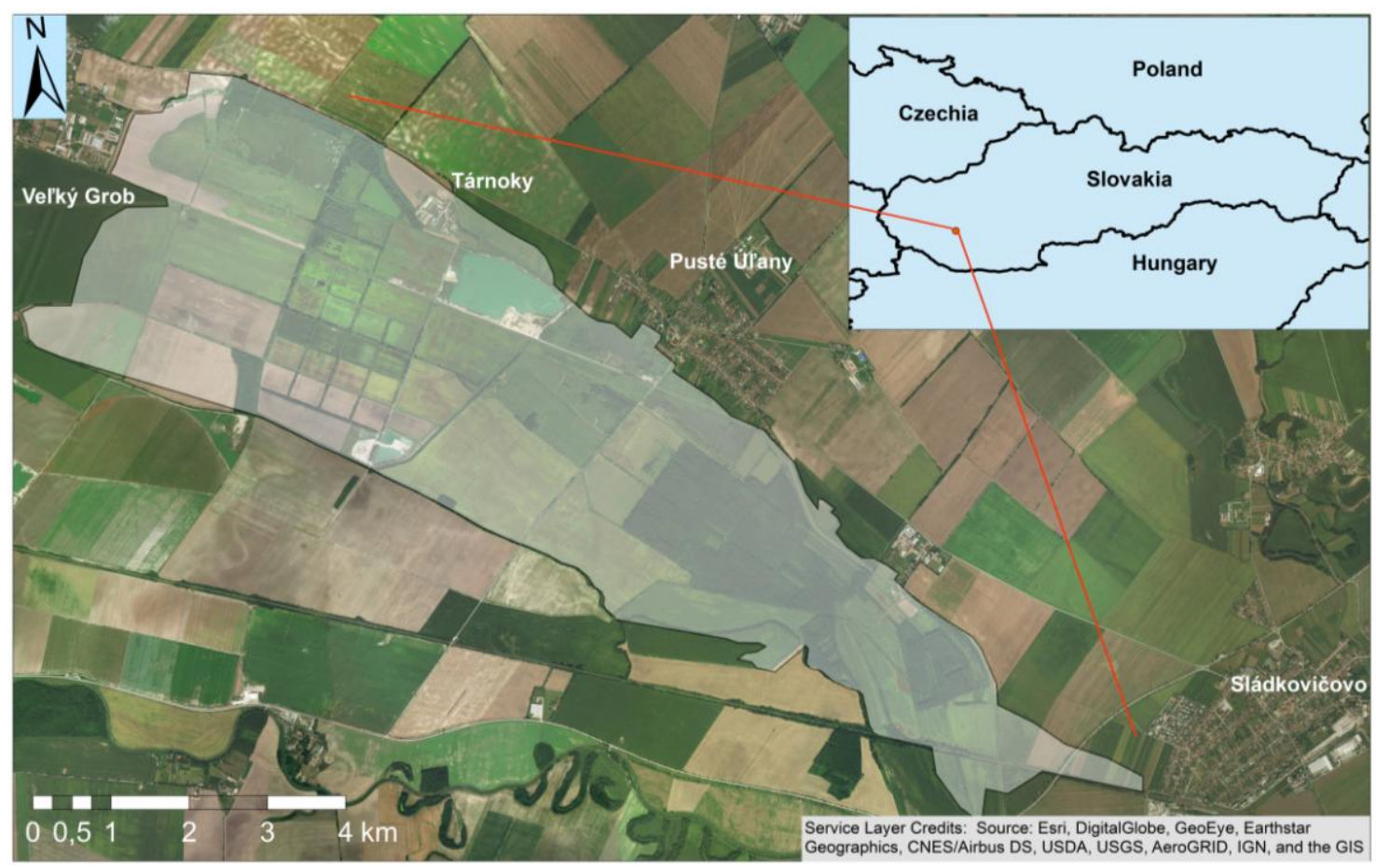

Figure 1. Current area of water-bounded communities reach in the mire near Pusté Úl'any

Secondary landcover structure reflects the changes of the last century, mostly intensification in landuse with typical deforestation for crops, which after 1. and 2. world wars started to be cultivated with automated machines and it formed the highest area of use in 1950s (Kopecká, 2011). Soil substrate is characteristic by the very fertile soil types like chernozem or fluvic mollisols, so the cultivated land is in the direct proximity of the mire. Area of mire that is too waterlogging is not suitable for cultivation and that is why even more intensive draining of this area took place in the past (Hreško and Guldanová, 2012). In 1950s the intensification was finalised by peat extraction (Krippel, 1956), which degraded the landscape of this mire and large water areas - peat extraction lakes were formed with accumulated water.

\section{Methodology}

$D E M$

Digital elevation model was obtained from National Institute of Forestry (Zvolen). Measuring took place with terrestrial laser scanner (TLS) with $50 \mathrm{~cm}$ cell size of raster resolution. Outputs were processed in AcrGIS environment, version 10.3.1. 


\section{Historical maps}

Series of historical maps were analysed and vectorised in ArcGIS environment (version 10.3.1.) and on its basis the spatial differentiation of landuse was reconstructed in several time horizons. Also original area of the mire was determined. Maps of greater and middle scales from the eighteenth and nineteenth century were used, including military surveys (1.m.m. in 1782-1785 and 2.m.m. in 1839) and map based on cadastral maps in the end of nineteenth century. Separated cartographic sources are cited in the list in the end of this article. In text interpretation we used map portal (Topographical Institute in Zvolen) - aerial scanning orthophotomaps in 1949 (http://mapy.tuzvo.sk/HOFM/). Actual state of the landcover was evaluated with orthophotomap in basemap 2018 (CArcGIS).

After transformation of the historical maps to currently used S-JTSK coordination system, selection of the maps was used. Work with map of „Vestigium operationis...(number 1 in the list of cartographic sources cited in the end of this article in bibliography) was possible to rectify only with points of village establishments (churches) as main orientation points or for example Esterházy palace near town Senec. Anyway the mean error is too excessive. Map Comitatus Posoniensis...., published in 1757, is of better precision. However, the error of rectification was still notable (Table 1). Hence these too maps were visualized in text only as cut out section figures from the original maps.

The first and the second military surveys was available in better form already rectified on mapportal mapire (http://mapire.eu/en/), so it was easier to rectify map sheets already obtained from Hungarian Library (Hungaricana - Hungarian Cultural Heritage Portal) in digital form.

Table 1. Residual mistake of rectification (first polynomial transformation) in georeferenced historical maps (years 1757 and 1760)

\begin{tabular}{|c|c|c|c|c|c|}
\hline Year & Name & $\begin{array}{c}\text { Number of } \\
\text { maps }\end{array}$ & $\begin{array}{c}\text { Mean error of } \\
\text { transformation }\end{array}$ & $\begin{array}{c}\text { Number of } \\
\text { control points for } \\
\text { transformation }\end{array}$ & $\begin{array}{c}\text { Type of } \\
\text { transformation }\end{array}$ \\
\hline 1757 & $\begin{array}{c}\text { Map of Bratislava coun ty } \\
\text { (Comitatus Posoniensis...) } \\
\text { [S } 68 / \text { X. / No. 94.] }\end{array}$ & $\begin{array}{l}1 \text { cut out } \\
\text { section }\end{array}$ & 1345.54 & 11 & $\begin{array}{l}\text { First order } \\
\text { polynomial }\end{array}$ \\
\hline 1760 & $\begin{array}{l}\text { Csádé wetland mapping } \\
\text { in Bratislava district }\end{array}$ & Whole map & 133.242 & 5 & $\begin{array}{l}\text { First order } \\
\text { polynomial }\end{array}$ \\
\hline $1782-1785$ & 1. Military Survey & 2 sheets & 182.642 & 11 & $\begin{array}{l}\text { First order } \\
\text { polynomial }\end{array}$ \\
\hline 1839 & 2. Military Survey & $\begin{array}{l}3 \text { map } \\
\text { sheets }\end{array}$ & 50.750 & 9 & $\begin{array}{l}\text { First order } \\
\text { polynomial }\end{array}$ \\
\hline 1890-1897 & $\begin{array}{c}\text { Cadastral maps of } \\
\text { Bratislava district } \\
\text { (Pozsony megyei) [001- } \\
\text { 091] }\end{array}$ & $\begin{array}{l}4 \text { map } \\
\text { sheets }[56, \\
57,64,65]\end{array}$ & 67.088 & 17 & $\begin{array}{l}\text { First order } \\
\text { polynomial }\end{array}$ \\
\hline 1949 & $\begin{array}{l}\text { Orthophotomap of } \\
\text { Slovakia in } 1949\end{array}$ & $\begin{array}{l}1 \text { cut out } \\
\text { section }\end{array}$ & 23.569 & 6 & $\begin{array}{l}\text { First order } \\
\text { polynomial }\end{array}$ \\
\hline
\end{tabular}




\section{Biotope mapping}

Actual state of biotopes was reviewed directly in ArcGIS environment (version 3.5.1.) using basemap. Standard methodology for biotopes mapping in Slovakia was used by Ružičková et al. (1996) by or photomaps interpretation and terrain confirmation. At first a preparation phase took place, obtaining necessary sources about research area forming the initial list of legend items. Boundaries of individual polygons were mapped from orthophotomaps and corrected during field work.

Boundary of the mire was depicted with consideration to the current area of depending biotopes with a ground water as the main factor of its origin. Since the biotopes mapping methodology in Slovakia came through some development in recent years and it has several specifics adapted to our landscape (different type of biotopes with range from lowlands to highlands), we decided to use the older methodology of biotopes mapping (Ružičková et al., 1996), as it differentiates the anthropogenic biotopes on the very detailed level that were necessarily needed. Appertaining English name was referred to the original Slovak names and codes of the biotopes. Finally, corresponding codes of biotopes for new methodology of mapping was attached to the table as well as NATURA 2000 code equivalent if available.

\section{Results}

\section{Notes to the georelief topography}

Mire near Pusté Úl'any is a part of the Úl'any depression. Digital elevation model (DEM) displays the Úl'any depression and shows the higher position of adjacent Trnava Upland (about $15 \mathrm{~m}$ higher) in the NE position of the allocated research area (Fig. 2).

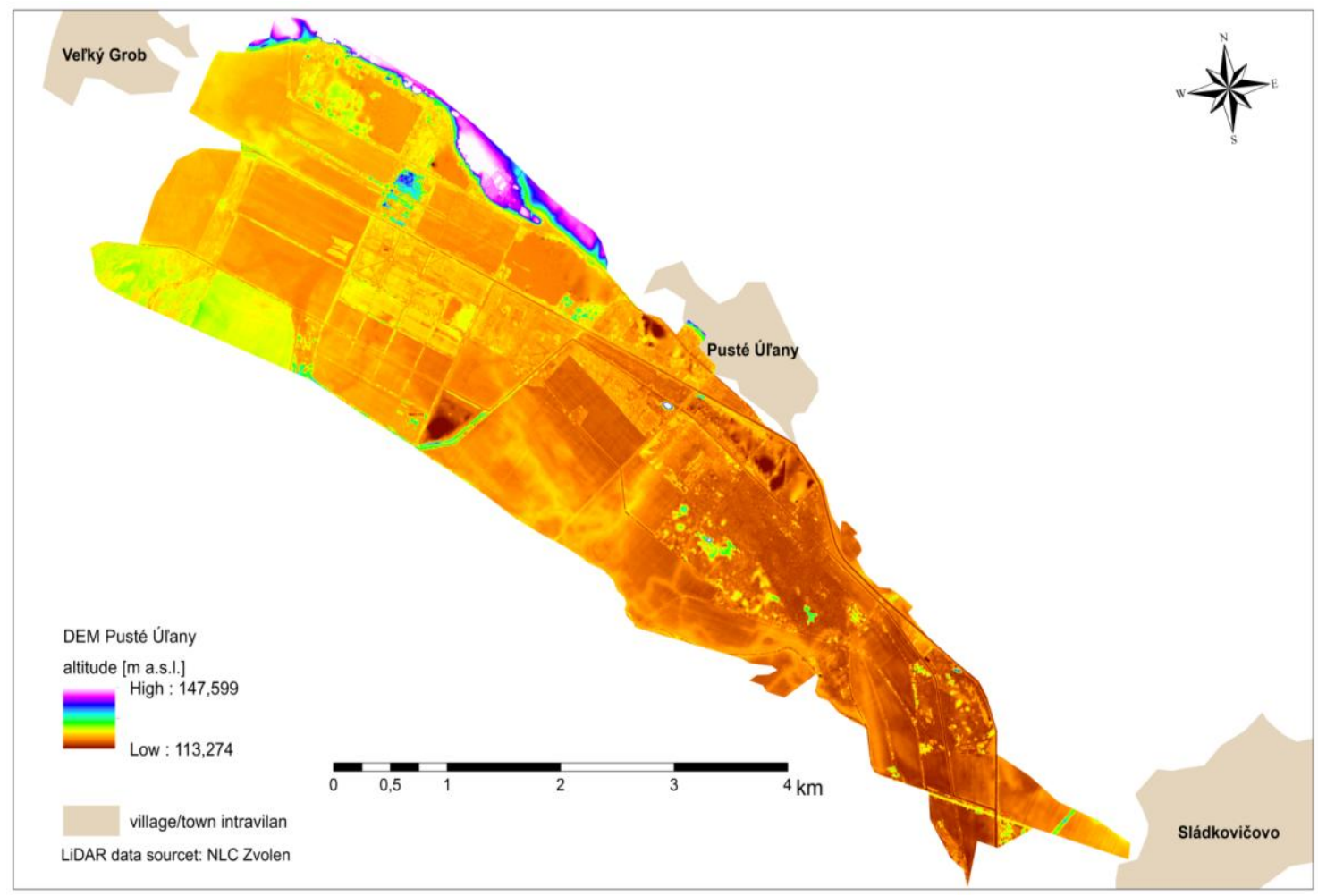

Figure 2. Digital elevation model of the wetland area near Pusté Úl'any 
Depression is descending in SE direction along the Pusté Úlany village continuing down to the south. The vertical segmentation of the terrain is $34.3 \mathrm{~m}$. Sedimentary basin was probably much larger than today, however the remains of the depression influenced by ground water is concentrated in the part close to the boundary of the tectonic slit between the Upland and the lowland. Generally, the highest parts of the area over $135 \mathrm{~m}$ a.s.l. are located in the northern part and the lowest parts below $120 \mathrm{~m}$ a.s.l. are concentrated in the south of the research area. NE part of the area on Figure 2 is showing the edge of Trnava Upland part. The actual mire is located in the elevation between $128 \mathrm{~m}$ a.s.l. and $114 \mathrm{~m}$ a.s.l. The bottom parts of the extraction lakes (116-113 $\mathrm{m}$ a.s.l.) are ascending on the colour spectrum as a result of peat extraction and consequential terrain subsidence. Gravel extraction is still in progress in the area. Some of the appeared upper parts of the DEM are caused by anthropogenic structures and others by vegetation cover, therefore these were further investigated directly during field research. This area represents the humid alluvial depression between merging two river flows: Stoličný stream around, which this wetland area is formed now, discharges into the Čierna voda River. This area between two water flows is contributing to the humidity storage.

\section{Historical maps and literature sources}

First detailed information about the mire near Pusté Úl'any came from Matthias Bel and his work Notitia... (Bel, 1736, Volume 2, Section VI.) which contains a detailed descriptions of villages located in administrative region of the Outer Bratislava District (Processus Superior Externus). Significant is a passage about Pusté Úl'any village where it stands that to the south of the village there is an area suffering from frequent floods. "There is a low-lying ground so boggy, that it is not able to hold even people, nor cattle on the ground, that are diving into it like into the swirls. This wetland is locally named Csádék. But after all, it brings some benefits to the local people as well, as it grows alders, suitable for extraction" (page 189). Important information about the mire are as well in description of Blatné village: „From this point $(=\mathrm{i}$. e. Červený vrch Hill) a large wetland plain starts to extend with numerous lakes between the villages Čataj, Nemecki Grob, Senec, Král'ová, Réca, Boldogfalva and Pusté Úl'any, or even further. In the favourable years it is typical with rich grasslands, but if the weather is too rainy it is easily covering in mud. From (this swamp) some people also derive the name of the village Blatné (Sárfö in Hungarian; sár means mud, therefore Sárfö means "head of a swamp"). Matthias Bel also mentions the possible benefits of regulation of the stream Sisak (Sziszak) and its conversion from wetland to meadows (Bel, l.c., page 195 and 196).

The first volume of the work of Mathias Bel (1735) also contains the first and in this time very geometrically precise map, covering the area of the mire. It is the map of Bratislava County authored by Samuel Mikovíni in 1735 (number 2 in the maps citation list). For the aim of our work, its easily available Homann's edition from 1757 (number 3 in the maps citation list) was used. Map of Mikovíni as a cartographic source significantly integrates the text information from $\mathrm{M}$. Bel. It also directly relates to another, somewhat older Mikovíni map Vestigium Operationis AstronomicoGeometricae (number 1 in the maps citation list), which is probably the oldest and relatively accurate projection of the mire (Fig. 3). This map was originally part of a letter, where Mikovíni drafted the principles of his method of the maps compliance (Purgina, 1958). According to these maps the waterlogged area and/or wet meadows 
stretched from the Vel'ké Úl'any village neighbouring the Pusté Úl'any village continuing to the Čataj and Blatné, while from the western part it was protruding to the Boldogfalva. In general, it covered much larger area as it is nowadays. It is interesting that this wetland area was the very factor of connection for currently two separate settlements - villages Vel'ké Úl'any and Pusté Úl'any. Originally both were a part of one larger settlement during the Middle Ages, its inhabitants first mentioned as "apiary" (meaning beekeepers), later in 1221 as "Fudemus" in Hungarian language. The whole area reaching also the disappeared village of Dudvágszeg was later divided between several owners (Sedlák, 1994). Even map of Mikovíni (1735) has an interesting detail marked near Pusté Úl'any village - map sign for the lonely standing church and farmstead (Tárnok). It was a remnant of the additional disappeared medieval village of *Tovarníky, that existed in thirteenth century (mentioned in 1301 as a nobleman's settlement). The assumption that the villagers were dealing with trade is also supported by the patronicium of the local church: St. Jacob was the patron of traders (Sedlák, 1994).

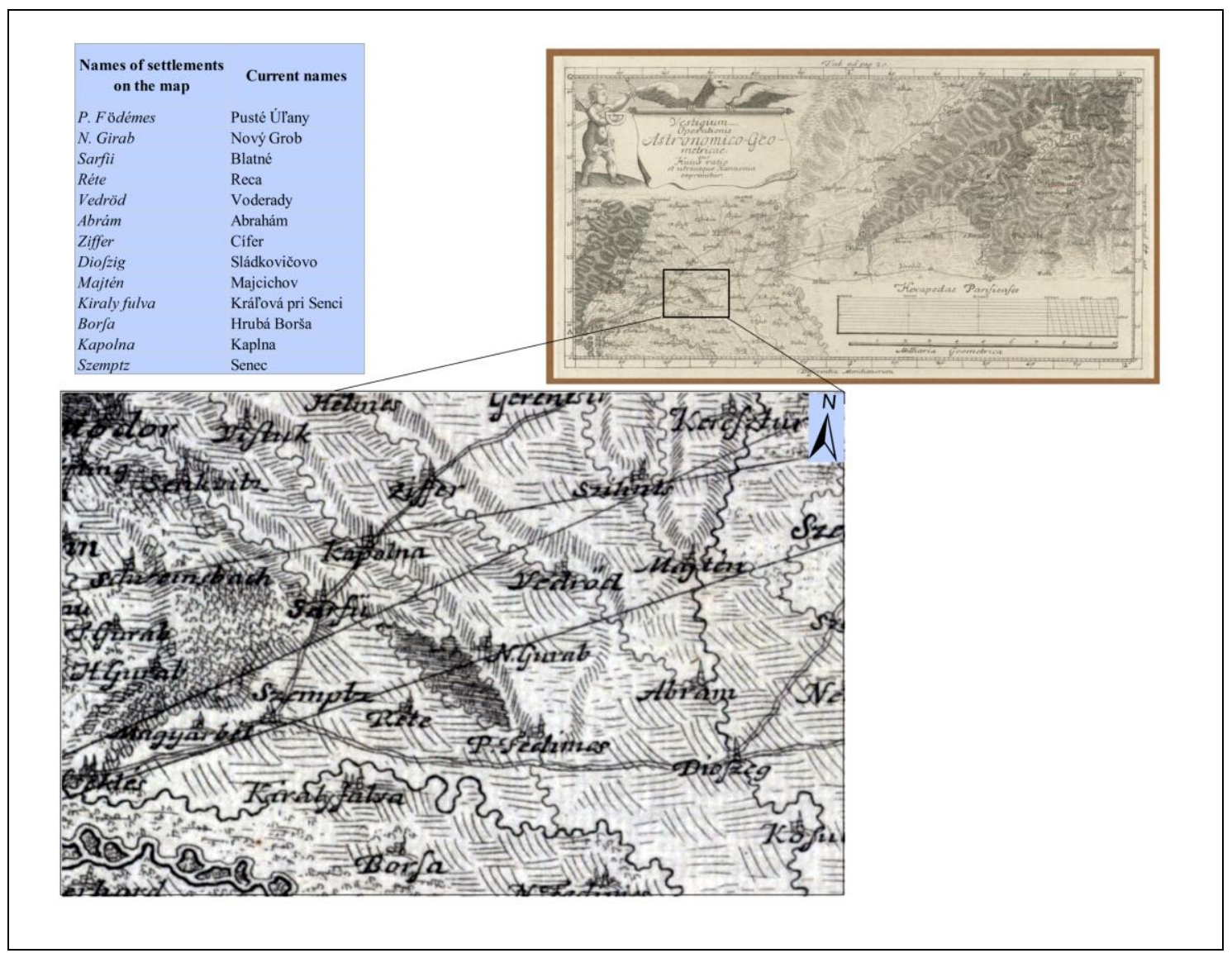

Figure 3. Mire near Pusté Úlany plotted on the cut out section from the map "Vestigium Operationis...". (Cited as number 1 in cited maps section) authored by Mikovíni, 1732)

For the history of draining the studied territory a map from the second half of the eighteenth century (approximately dated to 1760, map number 4 in the maps citation list) is of key importance. This map represents the oldest detailed cartographic depiction of mire, or in other words the area from the mouth of the Čády stream into the Little 
Danube (i. e. in to the Čierna voda river: "Influxus aquae Csády ad minorem Danubium") up to the Blatné village (Sarfö) in the North. The most humid terrain was in the middle and lower parts of the bounds of Vel'ký Grob, Továrniky and Pusté Úl'any. From the North the wetland was supplied by the waters from the Little Carpathians Mts. including the Vištuk brook, that was dividing into two separate branches near Čataj village and these two streams were surrounding the wetland area by each side. The key element of the map is a depiction of new drainage canal - Novus Canalis exsiccatorius, that begins on the boundary of the bounds of Borša, near Pusté Úl'any copying the edge of Trnava loessic pseudoterrace and flowing into the side river channel near the town Sládkovičovo - Dioszég (Naturalis Alveus Dioszegiensis). The main straight channel also had a three shorter side branches. Four bridges were built through the channel to facilitate passing communications. Even the map has no legend at all, it is possible to conclude it actually represents the first project of draining this mire or it was made shortly after excavation of the canal as the previous maps did not contain this structures.

The identical condition of man-made canal is shown on the map of the First Military Survey two decades later (maps number 5 and 6 in the maps citation list). It is obvious from these maps that also a stream called Sisak from Šenkvice village was flowing into the wetland from the North as well and this very stream gave a name to the artificial drainage canal - Sissak Graben (ditch "Shishak"- Šišak in Slovak language). The hydronyme comes from the Croatian colonists from Šenkvice village and its variable name is still being used as Šifák, Sifák, Sisak or Sisek (Beláková, 2014). New element on this map are two additional narrow drainage canals marking the boundaries of *Továrniky settlement, flowing into the main drainage canal. The area of the mire in this stretch was thus changed to meadows and pastures. In the southern parts there are visible at least two open water areas, marked on this map. One of this water areas is named See Tsadek - lake Čádek (Figs. 4 to 8; Table 2).

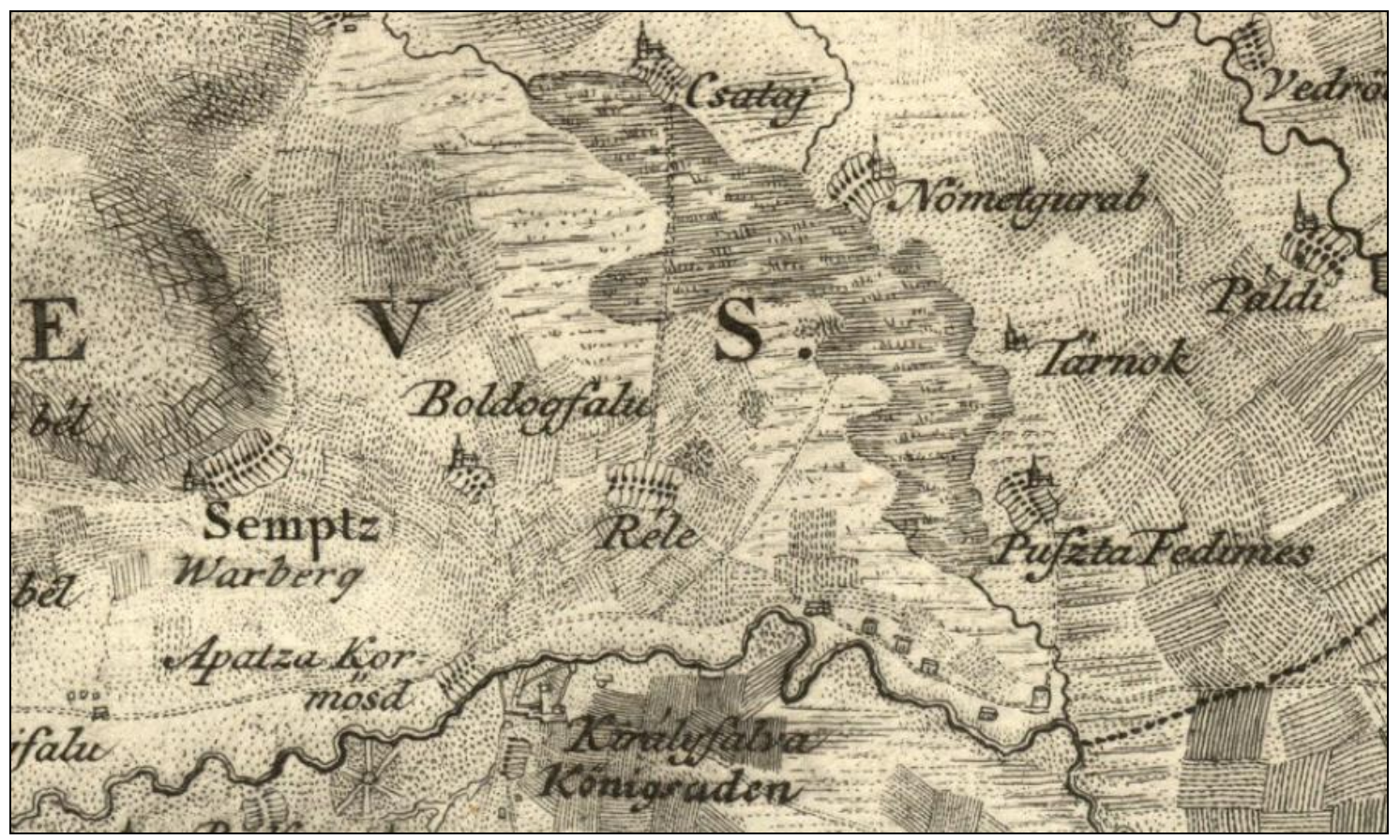

Figure 4. Cut out section of "Comitatus Posoniensis....." map [S 68-X. - No. 94] in 1735 showing mire near Pusté Úl'any. (Cited as number 2 in cited maps section) 


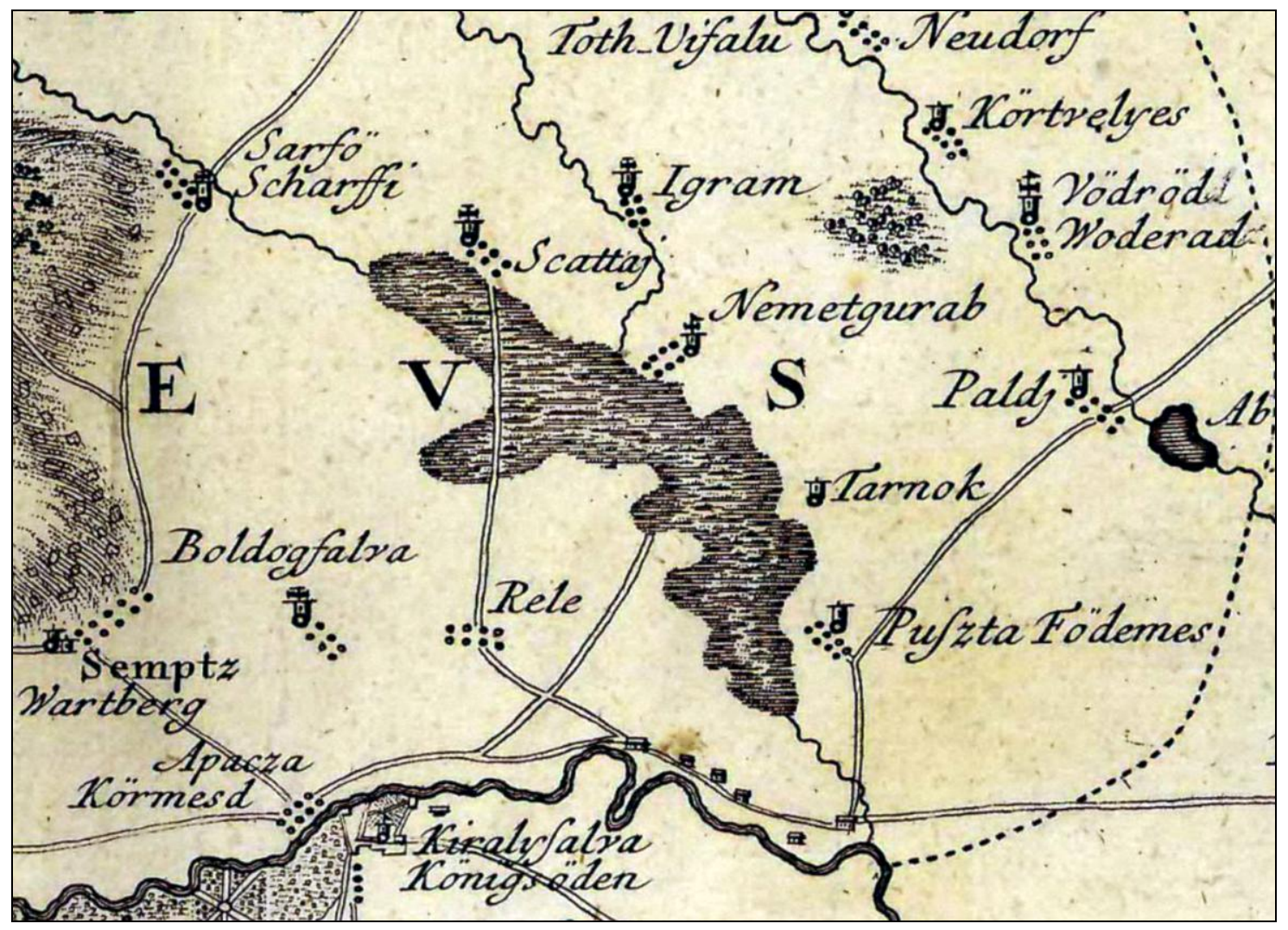

Figure 5. Cut out section of "Comitatus Posoniensis..." map [S 68 -X. - No. 94] in 1757 showing mire near Pusté Úl'any. (Cited as number 3 in cited maps section)

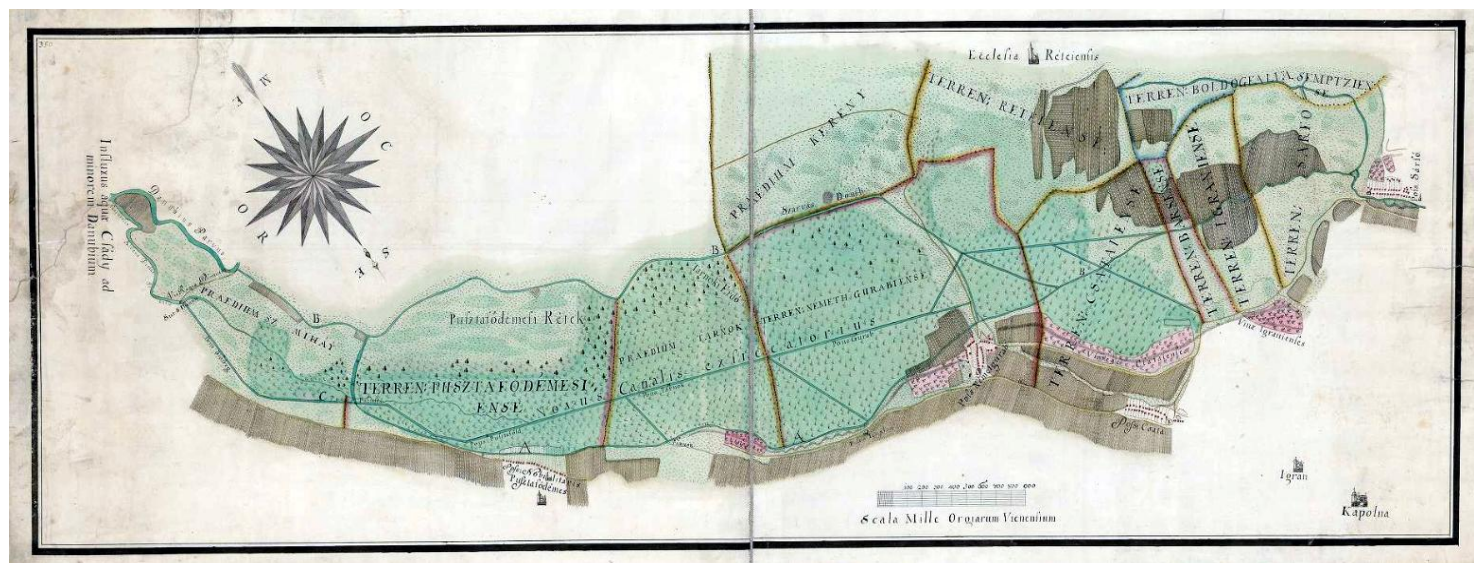

Figure 6. Map of the mire near Pusté U'l'any from second half of the eighteenth century with a first sketch of the drainage canal system

Table 2. Local names on the 1760 map and their meanings (Fig. 4)

\begin{tabular}{c|c|c}
\hline Local Latin name on the map in 1760 & Present name of location & Accurate English translation \\
\hline Danubius Parvus & Malý Dunaj & Little Danube \\
\hline Ecclesia Réteiensis & Reciansky kostol & Church of the Réca village \\
\hline Naturalis Alveus Dioszegiensis & Prirodzené rameno pri Sládkovičove & Natural channel of Sládkovičovo \\
\hline Novus Canalis exficcatorius & Nový odvodňovać kanál & New draining channel \\
\hline Pons Dioszeg(iensis) & Sládkovičovský most & Bridge of Sládkovičovo \\
\hline
\end{tabular}




\begin{tabular}{c|c|c}
\hline Pons Gurab(iensis) & Most k Vel'kému Grobu & Bridge od Vel'ký Grob \\
\hline Pons Pusztaföld(iensis) & Pusto-Úl'anský most & bridge of Pusté Úlany \\
\hline Pons Tárnok(iensis) & Tovarnícky most & Bridge of Tárnok \\
\hline Poss: (essio) & Obec, dedina & Village \\
\hline Poss: (essio) Csata & Obec Čataj & Village Čataj \\
\hline Poss: (essio) Németgurab & Obec Vel'ký Grob & Village Vel'ký Grob \\
\hline Poss: (essio) Nobilitaris Pusztafödémes & Šl'achtická obec Pusté Úl'any & Aristrocratic village Pusté Úl'any \\
\hline Praedium & Osada, majer & Farmstead, manor \\
\hline Praedium Kerény & Osada Kerény & Farmstead Kerény \\
\hline Praedium SZ Mihály & Osada Sv. Michal & Farmstead SZ Mihály \\
\hline Praedium Tárnok & Osada Tovarníky & Settlement Tárnok \\
\hline Pusztafódémeti Rétek & Pusto-Úl'anské lúky & Meadows of Pusté Úl'any \\
\hline Puszta Temptom & Pustý kostol & Lonely Church \\
\hline Stat: (ua) S. Ioannis & Socha sv. Jána & Statue of the Saint John \\
\hline Szarvas Domb & Dobytčí pahorok & Cattle hill \\
\hline Tárnok & Tovarníky & Tovarníky \\
\hline Tárnoki Erdó & Tovarnícky les & Tárnok's forest \\
\hline Terren (um) & chotár & Bounds, land area \\
\hline Terren (um) Boldogafalva & Chotár Boldogu & Bounds of Boldog \\
\hline Terren Németh Gurabiense & Chotár Vel'ký Grob & Bounds of Vel'ký Grob \\
\hline Terren (um) Pusztafödémesiense & Chotár Pusté Úl'any & Bounds of Pusté Úl'any \\
\hline Terren (um) Sarfö(iense) & Chotár Blatného & Bounds of Sárfó \\
\hline (Terrenum) Semptsiense & Chotár Senca & Bounds of Senec \\
\hline Via Regia Posonium & Hradská do Bratislavy & Highway to Bratislava \\
\hline Vinae & Vinohrady & Vineyards \\
\hline Vinae Igranienses & Čatajské vinohrady & Vineyards of Čataj \\
\hline & Igramské vinohrady & Vineyards of Igram \\
\hline
\end{tabular}

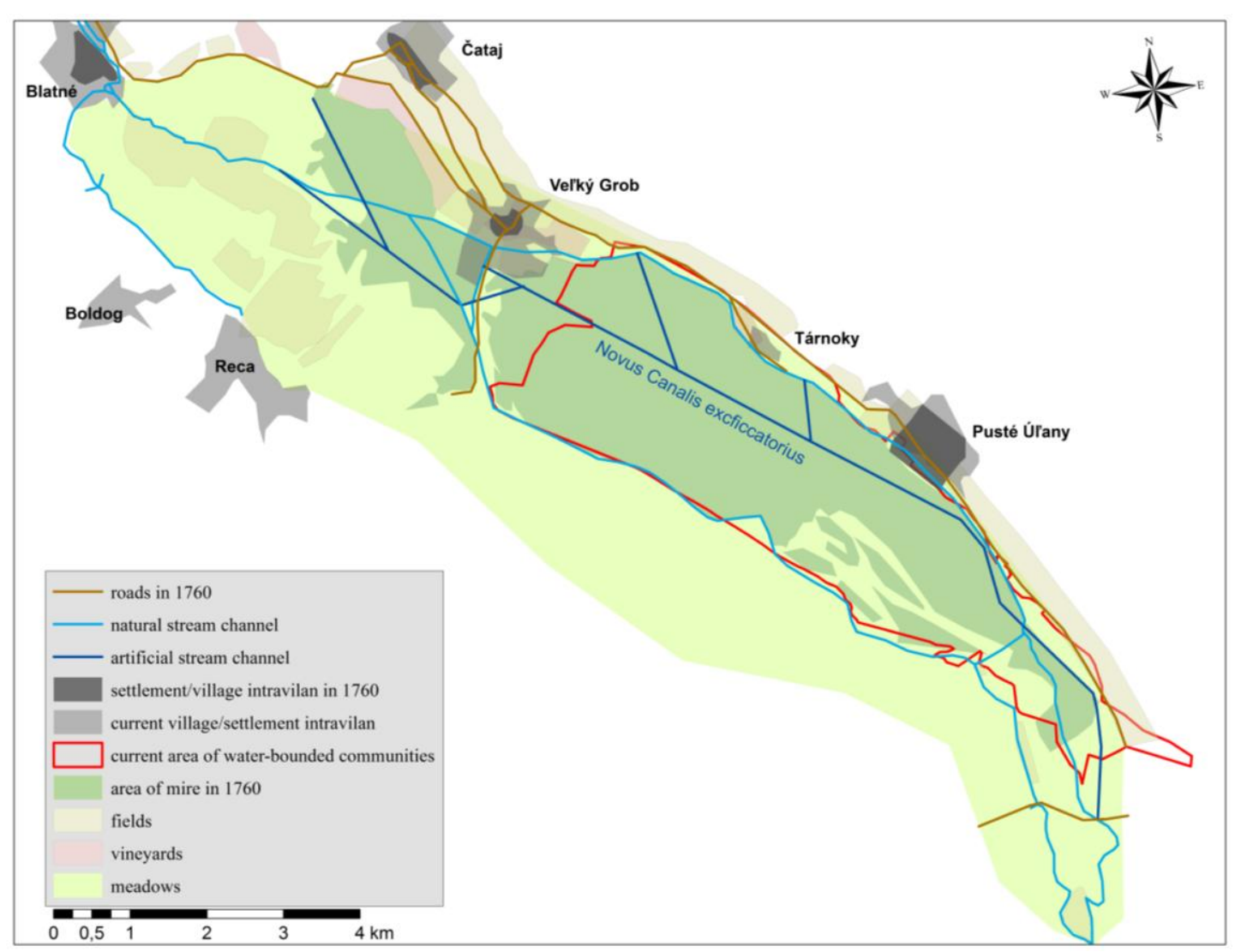

Figure 7. Area and Landuse of the mire near Pusté Úl'any around 1760 


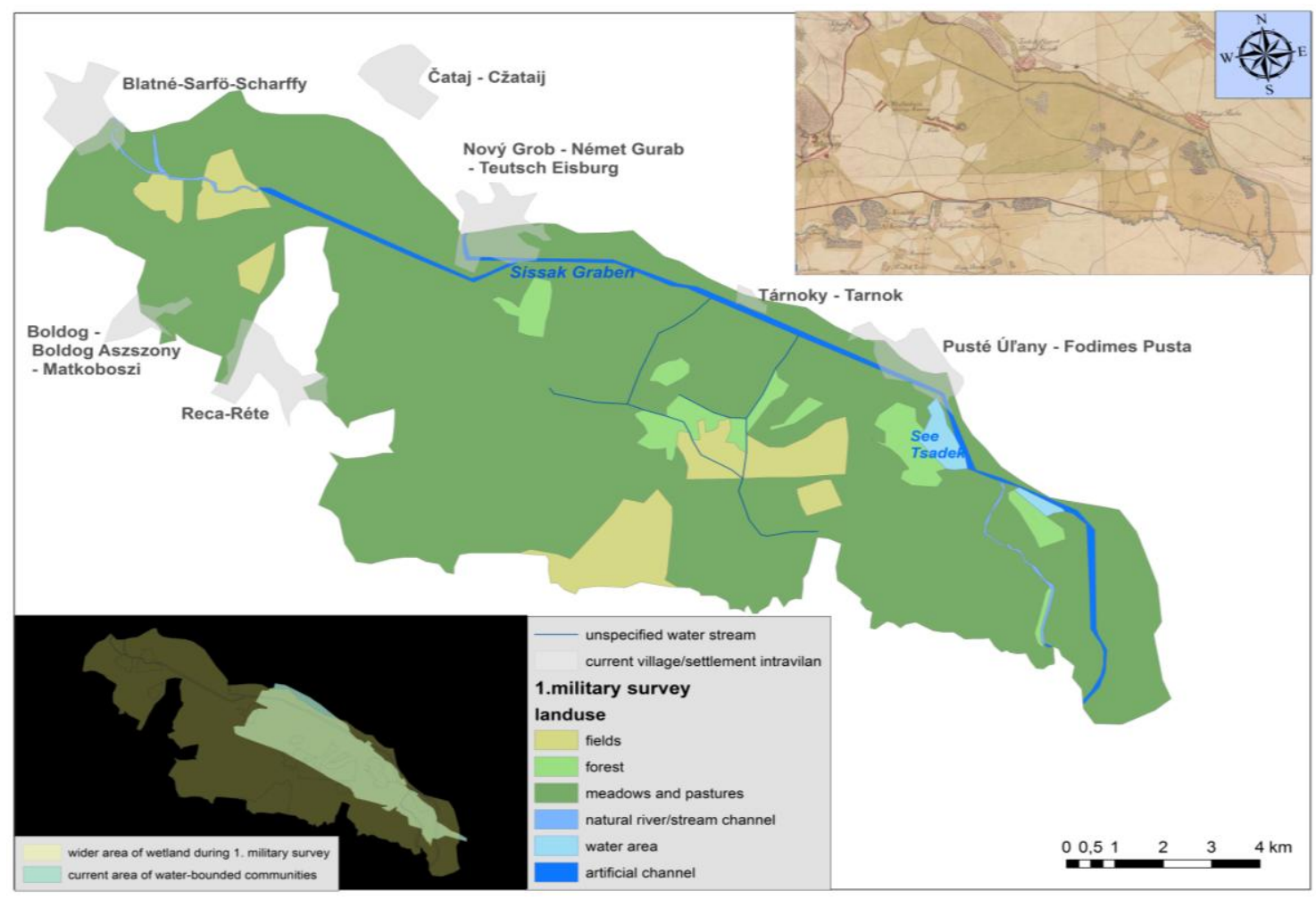

Figure 8. Area and landuse of the mire near Pusté Úl'any during 1. Military Survey (17821785)

The descriptive part of the 1st military survey also contains some notes available to the specific map sheet. At the description of Pusté Úl'any village (Pusta Födimes) and the *Tovarníky farmstead (Tarnok) is mentioned, that "the local meadows are mostly dry, gaining moisture only after rainy periods" (In German: "Die Wiesen sind nur bey Regen Wetter sumpfigt, ausser den aber trocken."). In contrast, the meadows of Vel'ký Grob village are usually dry (meist Trocken). In the "roads" column which mainly characterised the passability of the country for wagon convoys there is a statement that roads near Továrniky are "dry on the upland parts (Trnava Upland) but good and/or bad on the meadows in the lower grounds (= Úl'any depression), depending on the weather" ("...so wie das Wetter, gut und auch schlecht."). Also a mentions abouth local forests merits attention. For example, woods of the Vel'ký Grob village, located outside the artificial canal consists of young oak stands ("Das jenseits das Wasser befindliche kleine Wäld bestehet aus jungen Eichen."). Forests of Úl'any and Tovarníky situated between the meadows partly consist of thin scrubland (= cippiced alderwood?), and partly of the oak thickets (Die Waldung auf der Wiesen ... und ist theils schütteres Buschwerk, theils junge Eichenwaldung; Arcanum, 2004).

Interestingly enough, also a sketch of the mire on the respective map sheet from the Atlas of Korabinsky from 1804 (map number 7 in the maps citation list) is provided. In the area of Úlany map suggests a wetland area along the stream flowing into the Čierna voda (Schwartz Wasser). Mire, respectively the stream is named Tsadek (Čadek). Map has a sketch of drainage canal as well - Sissak Graben, which is marked incorrectly as it is heading from the Čadek influx into Čierna voda river to the Sládkovičovo town (Dioszeg), respectively Košúty village (Kossut) in Figure 9. 


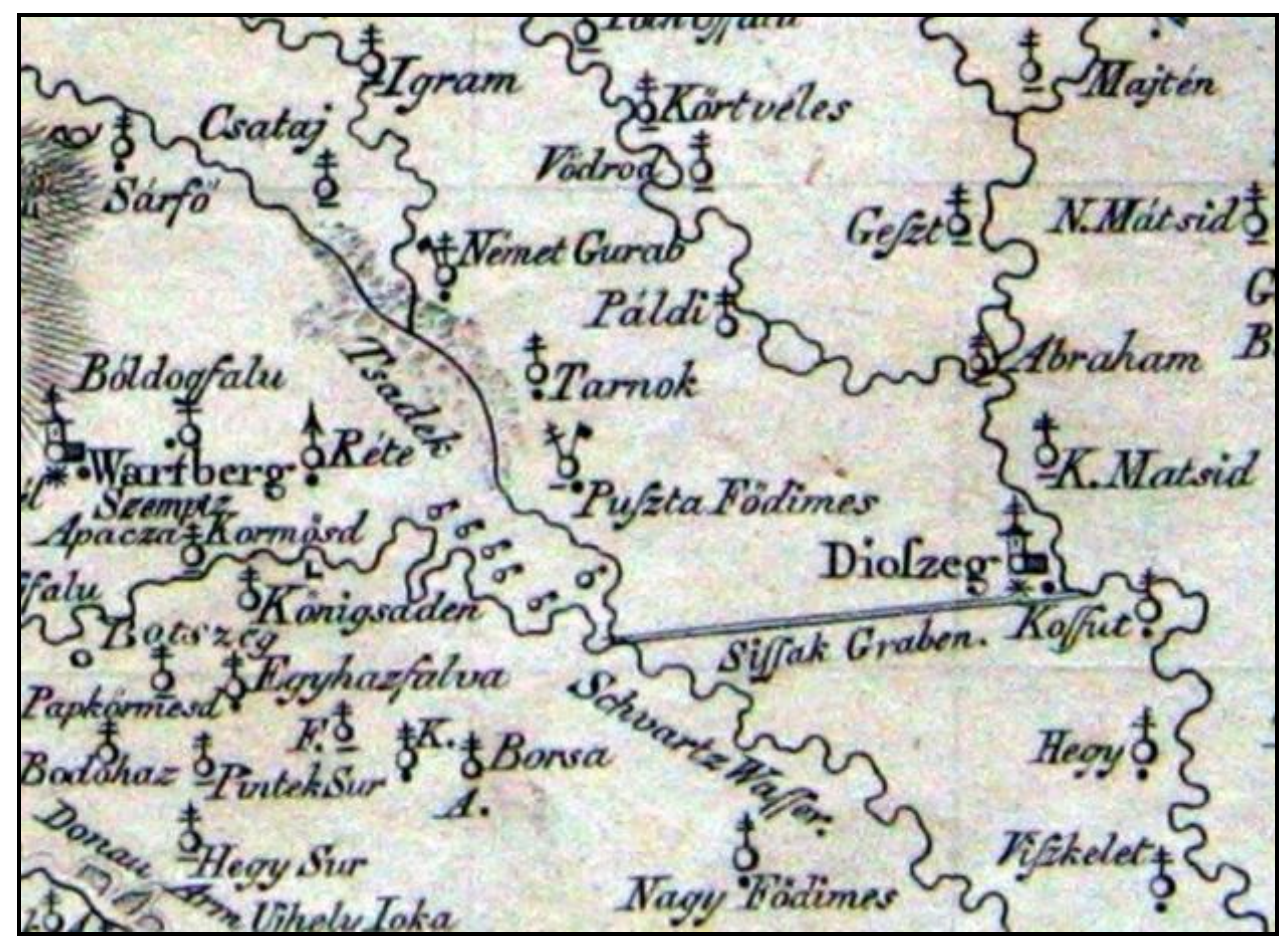

Figure 9. Stream Čádek (Tsadek) and the draining channel on the section selected from the Atlas of Karabinsky

On the map sheet of the 2. Military Survey (Fig. 10) from 1839 (map number 8-10 in maps citation list) there is the main drainage canal named Comitats Kanal, i. e. County Canal. This proves that the draining of the mire in the eighteenth century was organised and financed by the official bodies of Bratislava County. The main identifiable change on the map is a systematic draining of mire in the bounds of Továrniky by combined system of rectangular canals. These structures divided the area into square and rectangle shapes. It helped to convert the mire in this part from mire to meadows and pastures without no alder forest stands (Fig. 11).

On the map from the last 1890s (Map number 11 in the maps citation list), that originated by compilation of cadastral map sheets, the main drainage canal has a Hungarian name Megyei csatorna. The new element of the drainage system is except for more drainage canals, added to the existing system, is a new channel (Uj patak) localised from the Pusté Úlany village in the southern part of the mire area and other parallel channel in the bounds of Sládkovičovo (Magyar ée Német Diószeg in Hungarian language, Figs. 11 and 12).

Therefore, the mire used to reach more to the North in the past, but after draining of the territory most of the water was concentrated in the lowest parts of the mire and the upper parts were drained as the water flow distribution and outflow was accelerated.

During aerial scanning in 1949, the area consisted mostly of the arable land. After collectivisation the drainage of the area was more intensified and every possible part od the landscape was used as arable land. Mire was not really visible on these orthophotomap (number 12 in the maps citation list, Fig. 13). Krippel in his work from 1957 near Tovarníky settlement describes, that the top soil layer is drained and changed into typical fluvic mollisols, however there are rich peat sedimentary accumulation underneath this layer just about $90 \mathrm{~cm}$ to $270 \mathrm{~cm}$ deep (Krippel, 1957). 


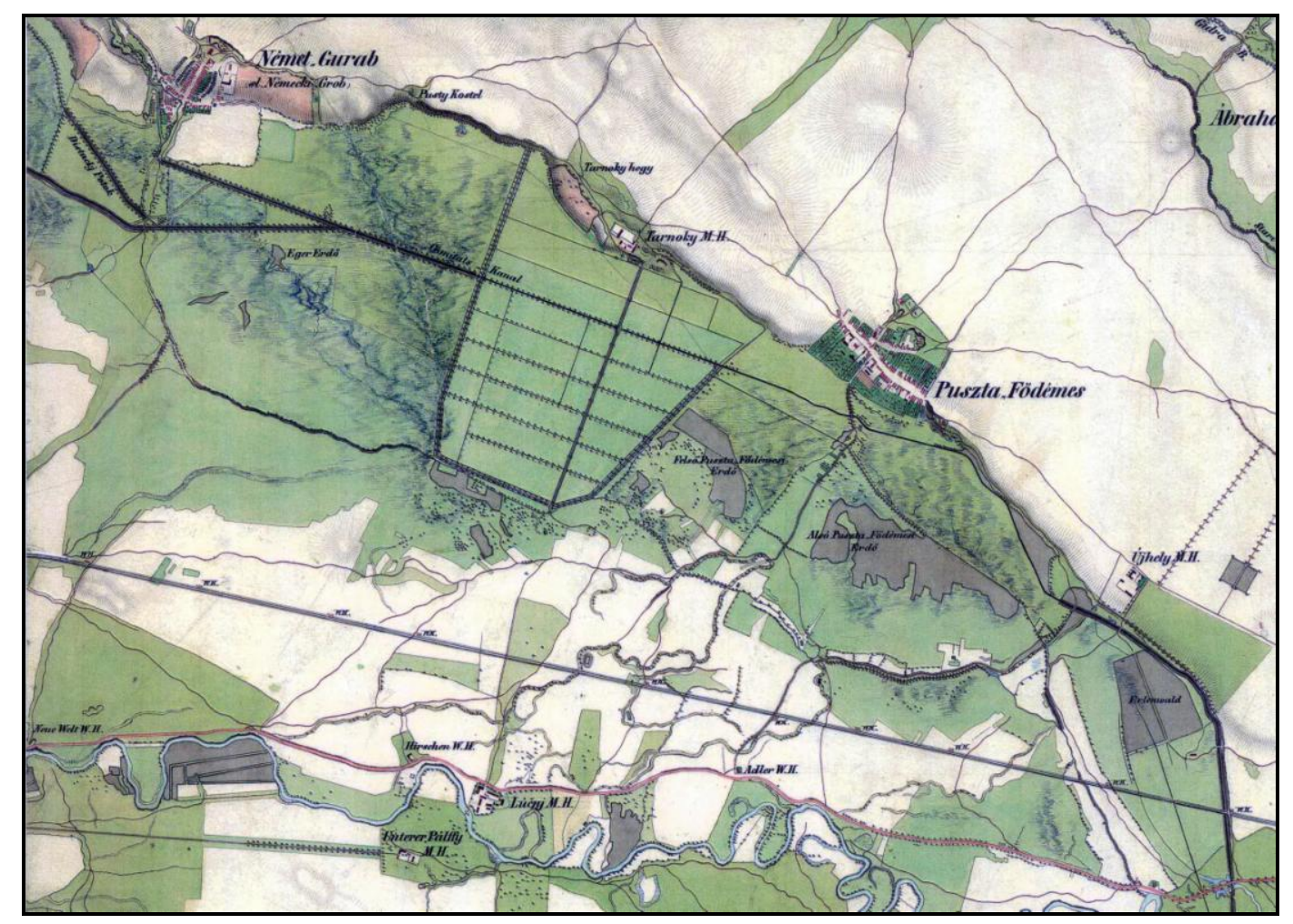

Figure 10. Selection from the 2. military survey showing the system of draining channel in bounds of Továrniky settlement built before year 1839

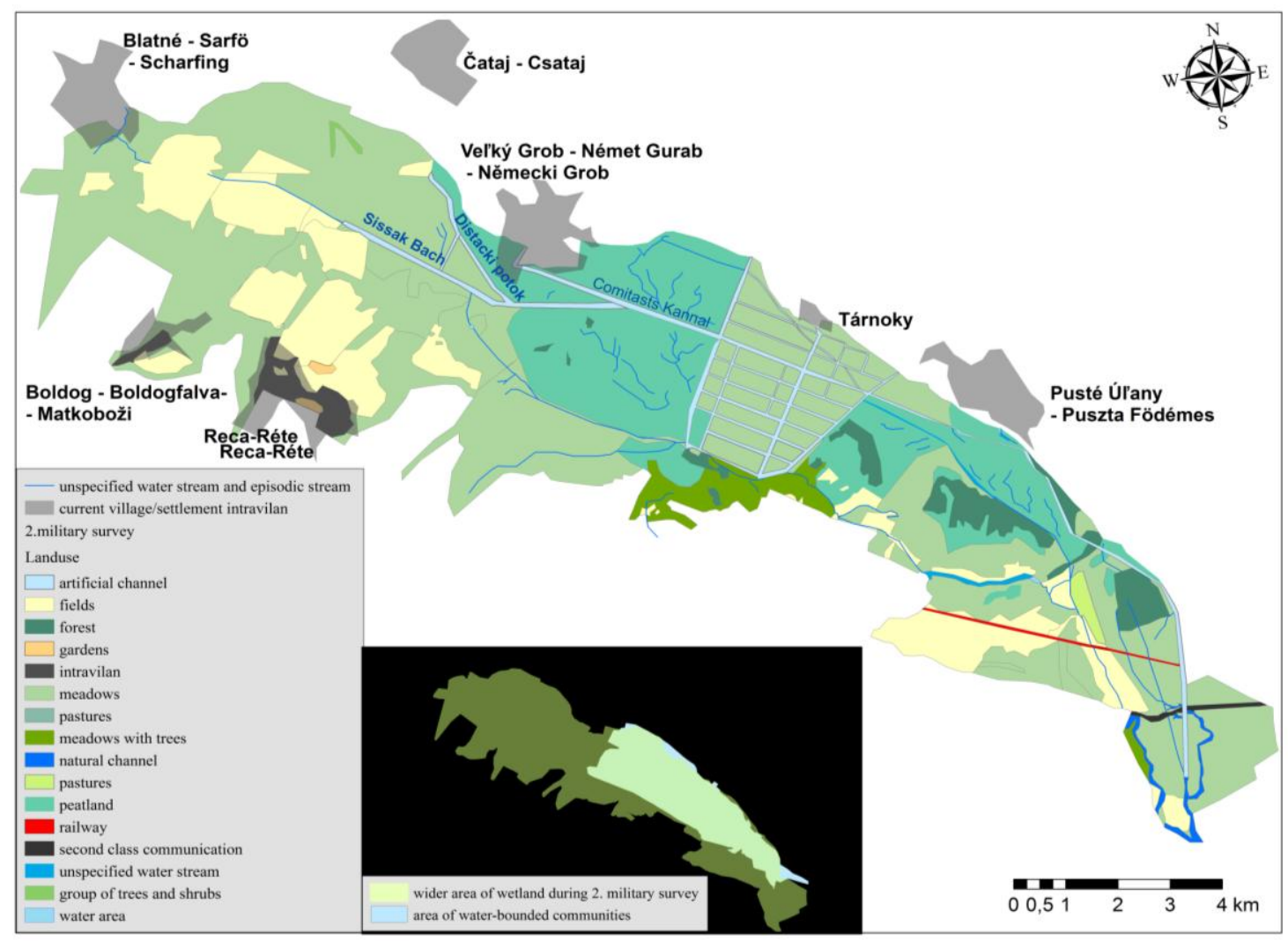

Figure 11. Area and landuse of the mire near Pusté Úl'any during 2. Military Survey (1839) 


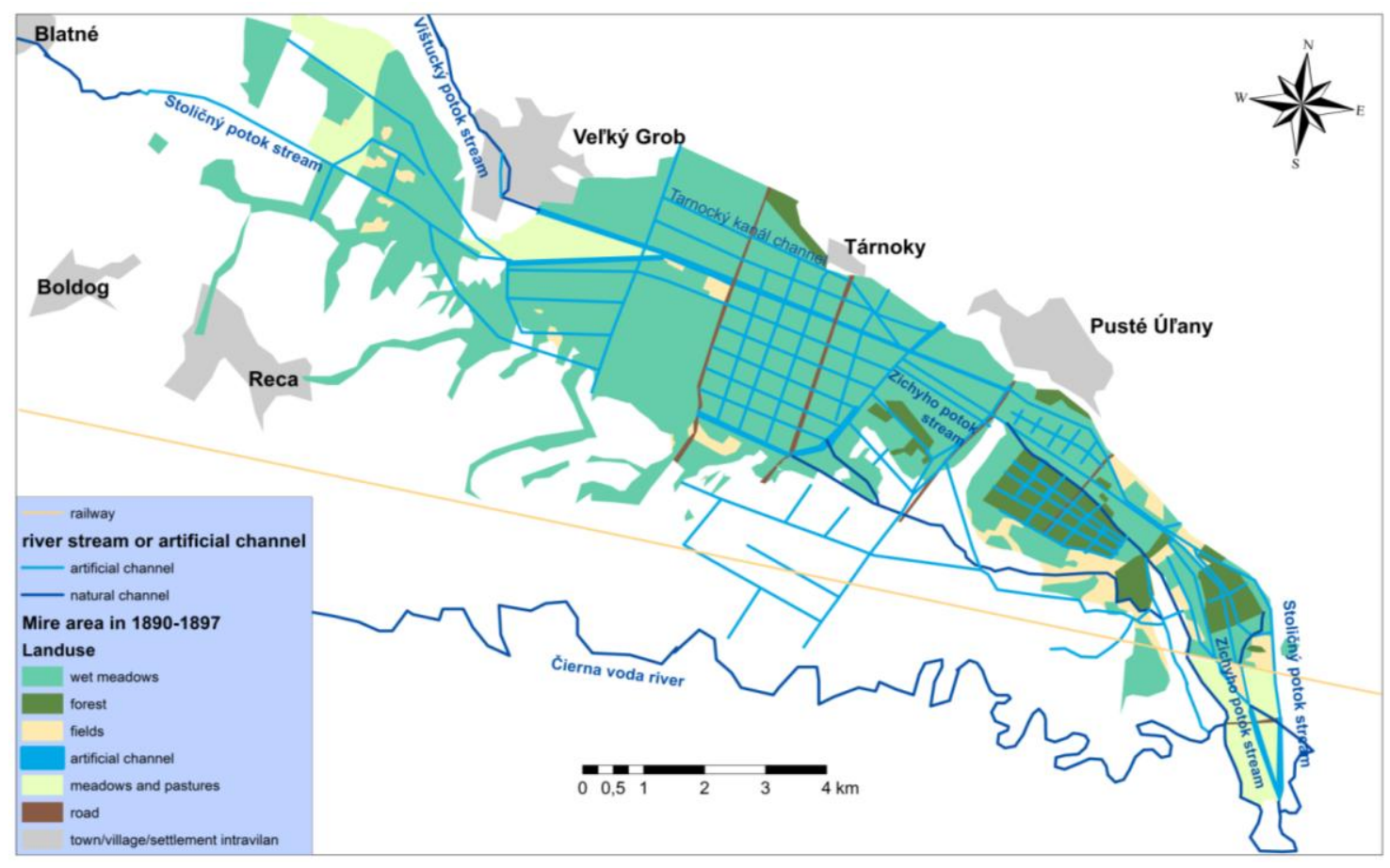

Figure 12. Area and landuse of the mire near Pusté Úlany on the Bratislava County historical map (1890-1897)

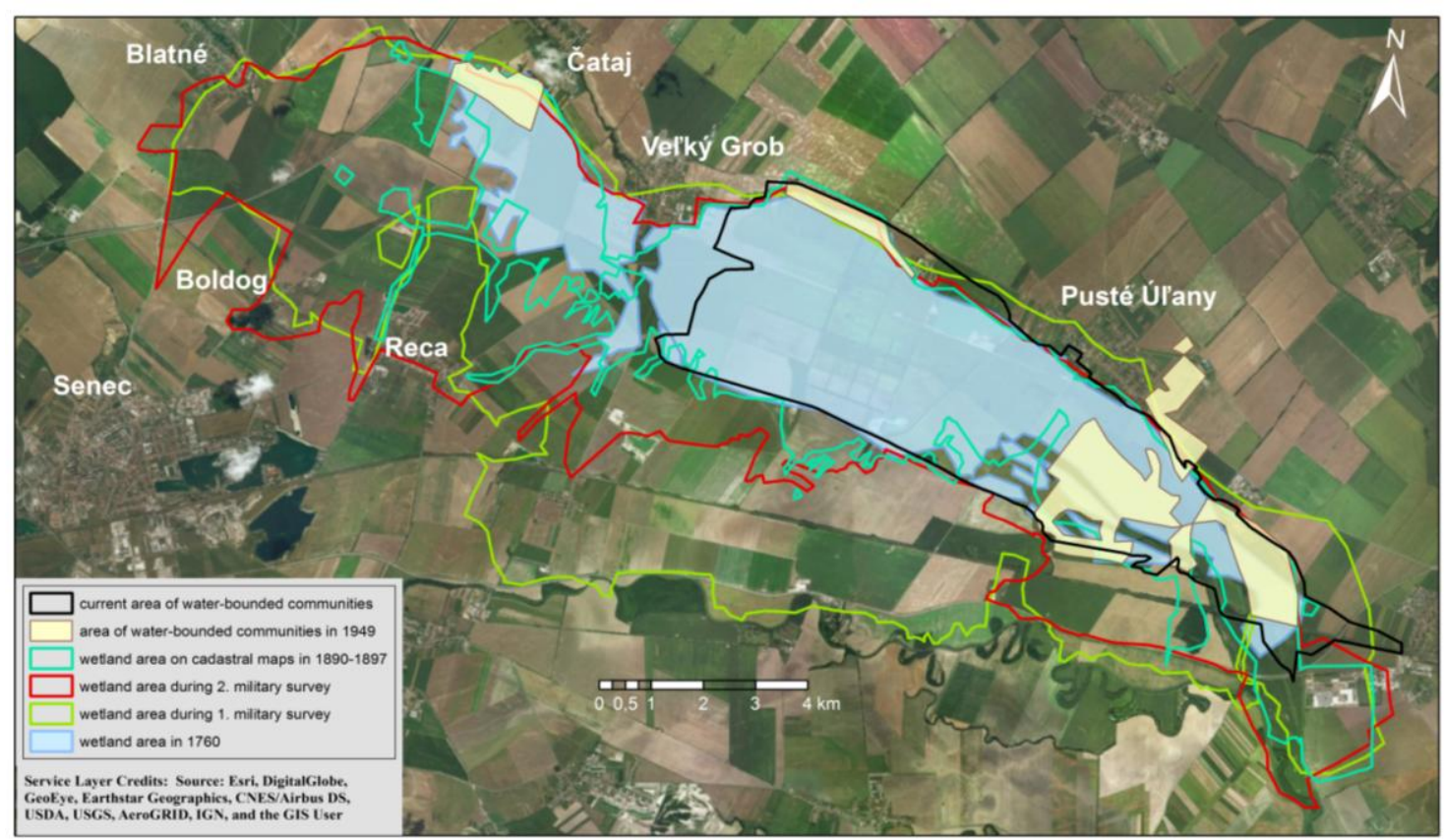

Figure 13. Change in the area of the mire near Pusté Úl'any in different time scales

\section{Biotope mapping}

By our research of current vegetation cover, the research area was set as the reach of ground-water influenced stands. The southern boundary was more difficult to isolate 
from the alluvium of Čierna voda stream, where originally the wetland area was probably stretched. The most of the area was covered with crops in 1949, however the ground water was still high in some years so it was difficult for tillage. The research area was mapped in terrain in the distance of the water areas until the signs of any humidification by ground water was present in the vegetation cover. This area is very reduced in present day as a result of long term human interference.

During the terrain research, several polygons of different water biotopes were identified. In our notes the bottom-rooted macrophytes and the bottom-rooted surfaceflowing macrophytes were determined. In the Tovarníky pond the species of Salvinia natans was identified. Large area of these extraction ponds is covered with hedges and reeds stands, especially on the edge of the open water areas of these ponds. Though, these areas are disturbed and degraded by local fishermen club as they are cutting reed stands in order to get the access to the open water area for fishing. Generally, these ponds are following the water succession and they are continuously overgrowing the open water area depending on the date of the extraction works shutdown. Originally, the mire was typical by alder and oak forest stands. Characteristic biotope with common alder (Alnus glutinosa, code 2111500) is present only marginally in the Tovarníky part of the mire. Close to this polygon the representative alluvial forest with Fraxinus excelsior and Ulmus carpinifolia at least fifty years old (present in the area on the orthophotomap in 1949 as well). Nevertheless, the typical alluvial stand of this type is missing the oak species (Quercus sp.).

The ground water level during field research in November (2016) was stable around $20 \mathrm{~cm}$ to 2 meters or more. The mean level was around $90 \mathrm{~cm}$ (found out during soil probes measuring near Tovarníky pond). Several drainage canals are overgrown by vegetation and they are ideal environment for bird nesting such as Asio flammeus (Vd'ačný, 2001) and other types of protected fauna. In the vicinity area of the extraction ponds the underground water level is higher and surrounding crops are currently not cultivated as they are subject to succession of different types of shrubs. In the southern parts of the wetland area, near Puste Úlany village the forested area is managed by forest management as poplar monocultures. This management supports the prevalence of invasive species in the herb vegetation layer, what is degrading the natural communities. Number of identified biotopes is 27 (Fig. 14; Table 3), from which the 13 types is purely of anthropogenic origin. It is remarkable there are several marginal areas of natural vegetation after major degradation in this area (2111500). Most of the area is used as arable land and major abandonment of the agricultural landscape is situated near the open water areas.

Table 3. List of mapped biotopes in the research area

\begin{tabular}{c|c|c|c|c}
\hline $\begin{array}{c}\text { Biotope code } \\
\text { (Ružičková et al., } \\
\mathbf{1 9 9 6}\end{array}$ & Biotope name (Ružičková et al., 1996) & $\begin{array}{c}\text { Biotope code (Stanová } \\
\text { and Valachovič, 2002) }\end{array}$ & $\begin{array}{c}\text { NATURA2000 } \\
\text { code }\end{array}$ & $\begin{array}{c}\text { Area } \\
\text { [ha] }\end{array}$ \\
\hline $\mathbf{A 1 1 0 0 0 0}$ & Intensive crops & $\mathrm{X} 7$ & - & 1021.794 \\
\hline $\mathbf{8 2 3 4 0 0 0}$ & Material pit & $\mathrm{V}$ & - & 108.8369 \\
\hline $\mathbf{8 1 5 0 0 0 0}$ & River/stream channel & Vo4 & 3260 & 24.5387 \\
\hline $\mathbf{8 1 6 0 0 0 0}$ & Regulated water flow & Vo4 & 3260 & 31.067 \\
\hline $\mathbf{A 5 2 0 0 0 0}$ & Roads & $\mathrm{X} 3$ & - & 1.6561 \\
\hline $\mathbf{2 1 1 1 2 0 0}$ & $\begin{array}{c}\text { Riparian forest with Quercus robur, Ulmus laevis } \\
\text { and Fraxinus excelsior }\end{array}$ & L.s1.2 & $91 \mathrm{~F} 0$ & 47.9479 \\
\hline
\end{tabular}




\begin{tabular}{|c|c|c|c|c|}
\hline 2122100 & $\begin{array}{l}\text { Artificial broadleaved forest (Chelidonio- } \\
\text { Robinion) }\end{array}$ & X9 & - & 4.6462 \\
\hline 2122200 & Artificial broadleaved forest with Populus & X9 & - & 194.545 \\
\hline 8A10000 & $\begin{array}{l}\text { Floating aquatic plants (Lemnion minoris, } \\
\text { Hydrocarition and Utricularion vulgaris) }\end{array}$ & Vo6 & - & 0.2883 \\
\hline 8А20000 & $\begin{array}{l}\text { Submerged bottom-rooted aquatic plants } \\
\text { (Parvopotamion, Magnopotamion p.p.) }\end{array}$ & Vo6 & - & 1.5137 \\
\hline $\mathbf{8 A 3 0 0 0 0}$ & $\begin{array}{l}\text { Surface floating bottom-rooted aquatic plants } \\
\text { (Nymphaeion, Callitricho-Batrachietalia) }\end{array}$ & Vo6 & - & 0.0089 \\
\hline $8 B 10000$ & Reeds in water bodies and mires (Phragmition) & Lk11 & - & 11.2704 \\
\hline $8 B 22000$ & Large Carex beds & Lk10 & - & 0.744 \\
\hline 3522100 & $\begin{array}{l}\text { Alluvial meadows and meadows in wet } \\
\text { depressions in lowlands and Uplands }\end{array}$ & $\mathrm{Ra} 7$ & - & 17.8485 \\
\hline $\mathbf{A 5 2 1 0 0 0}$ & Cart-road on the field & $\mathrm{X} 4$ & - & 10.3308 \\
\hline $\mathbf{A 5 2 2 0 0 0}$ & Forest cart-road & $\mathrm{X} 4$ & - & 0.1425 \\
\hline $\mathbf{A 1 1 3 0 0 0}$ & Ruderal weed communities near fields and roads & $\mathrm{X} 4$ & - & 26.2931 \\
\hline $\mathbf{A 3 0 0 0 0 0}$ & Building structures outside settlements & $\mathrm{Z}$ & - & 11.2375 \\
\hline A430000 & Abandoned mining sites & $\mathrm{X} 3$ & - & 159.1613 \\
\hline 2163000 & Self-seeding tree formations & $\mathrm{X} 2$ & - & 0.6939 \\
\hline 2162500 & Other type of shrubs & Kr6 & $40 \mathrm{~A} 0$ & 53.1088 \\
\hline 2161100 & Temperate thickets with Prunus spinosa & $\mathrm{Kr} 7$ & - & 5.9694 \\
\hline 2162300 & Glades with Sambucus ebulus thickets & $\mathrm{X} 1$ & - & 8.4551 \\
\hline A410000 & $\begin{array}{l}\text { Weed communities od recently abandoned urban } \\
\text { and suburban constructions }\end{array}$ & $\mathrm{X} 4$ & - & 9.7343 \\
\hline 2118000 & Pioneering tree formations & $\mathrm{X} 2 / \mathrm{X} 9$ & - & 24.7877 \\
\hline $\mathbf{A 2 0 0 0 0 0}$ & Anthropogenic forests & $\mathrm{X} 9$ & & 0.2886 \\
\hline 2111500 & Alder swamp forests (Alnion-glutinosae) & Ls.7.4 & - & 4.6239 \\
\hline
\end{tabular}

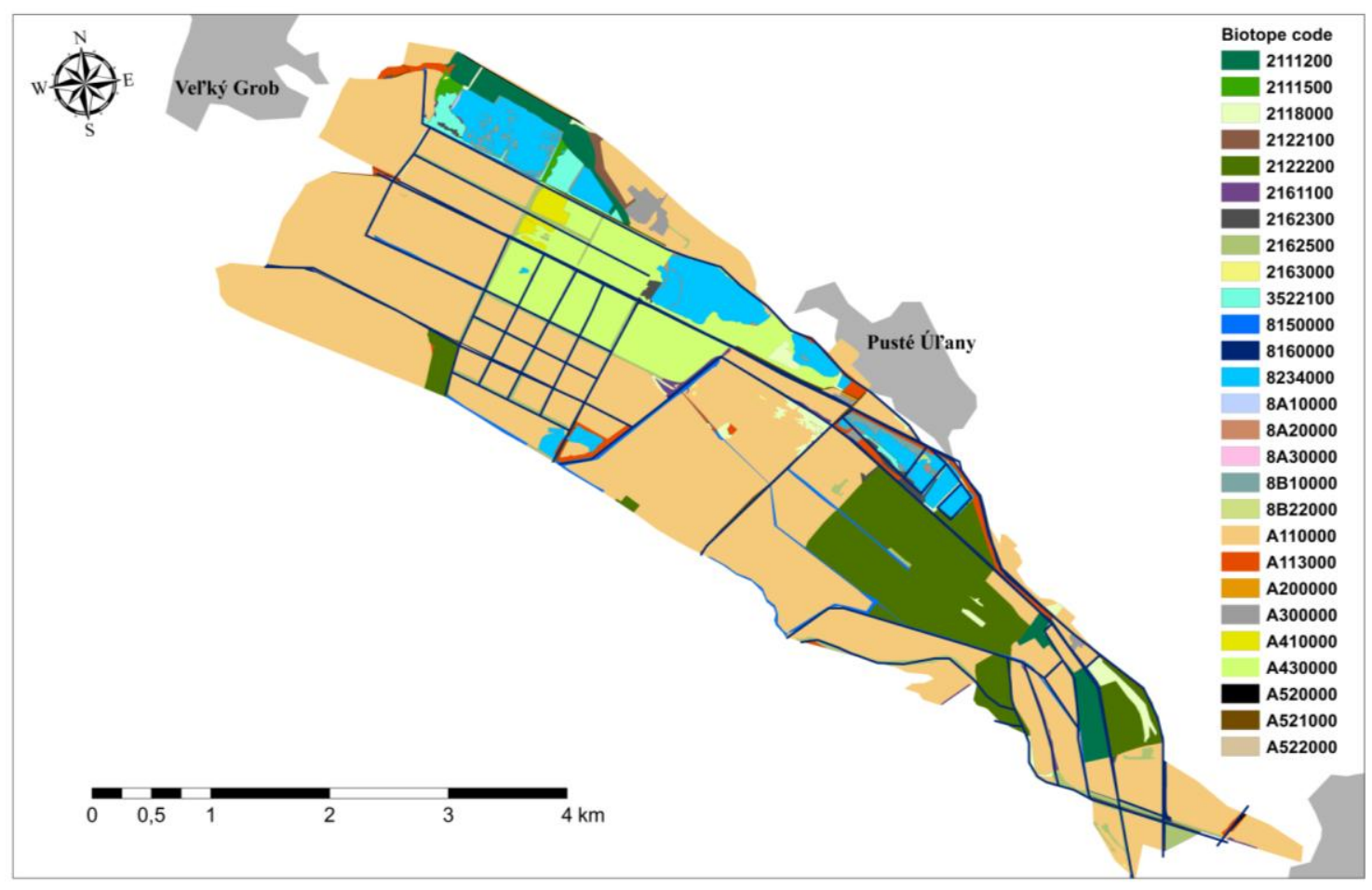

Figure 14. Map of biotopes covering the area of mire near Pusté Úl'any

APPLIED ECOLOGY AND ENVIRONMENTAL RESEARCH 16(4):5025-5045. http://www.aloki.hu • ISSN 15891623 (Print) • ISSN 17850037 (Online) DOI: http://dx.doi.org/10.15666/aeer/1604_50255045 (c) 2018, ALÖKI Kft., Budapest, Hungary 


\section{Discussion}

Human intervention can change the wetland landscape very dramatically (Guette et al., 2018). The similar changes in landuse of wetlands were mentioned as a result of collectivisation also in other countries of the Eastern bloc (Deak, 2007; Skalos et al., 2017; Jepsen et al., 2015).

Based on historical maps analysis it was found out that the area of mire had its active part in the north as well covered the area up to Blatné village, it would be better to have larger DEM in our possession. The mire was presented more as the wetland than the open water body mire area, and that is also the reason for difficulty of evaluating the mire activity in different time scales. As this area started anthropically induced drainage in eighteenth century it is really possible that a further research such as palynology or macrofossil analysis is needed to understand the genesis and the origin of the mire. However, it is depending on the further suitability of the sediment.

According to historical sources it was concluded that the mire was supplied by not only the Little Carpathians Mts's streams, but also by the high flows of the Little Danube. Historical name of the mire "Csádé" or Csádek respectively is probably an older Hungarian hydronyme (csádé, csáté) with meaning of "wetland" or "shrubs dominated land" (Czuczor and Fogarasi, 1862-1874). In southern part, the alder stands were historically prevailing for the longest time (Felsö Puszta Födémesi Erdö, Erlenwald, 1839; Egresi Erdö, 1897). Area of the mire and especially its extent to the south-west direction was dynamically changing. In dry years the meadows were productive, but in the wet years, meadows were more characterised as wetlands and deposition of the mineral sediments took place and the major part was impassable. In the deepest parts the open water areas were formed (lake Tsadek). At first the western part of the mire has undergone degradation (Vel'ký Grob - Blatné) after drainage canal construction in the second half of the eighteenth century. Hence the research was focused on the southern part as our major part for research of current biotopes (Vel'ký Grob - Pusté Úl'any). Yet historical maps need to be considered, as they were the part of the larger image, for example the historical map of whole Bratislava County (1957), where the mire drawing could be only estimation.

The drainage in the eighteenth century was very standard solution in the AustroHungarian empire. For the comparison the similar degradation was proceeded in Parížske močiare wetlands were the first drainage took place in 1819 (Procházka et al., 2015), but in the lake Súr near Svätý Jur the drainage took place only in 40. of the twentieth century (Pišút et al., 2010).

Currently the major problem of the prospected area is as well the abandonment of agricultural landscape, what is quite characteristic for the Eastern bloc countries (Lieskovský et al., 2015; Jepsen et al., 2015; Burgi et al., 2017). Landcover analysis in this area was described by Kopecká (2011) with emphasis to the protected bird's occurrence. The secondary landscape structure during the twentieth through to the twenty-first century was prospected in the Úl'anská wetland bird's area (Hreško and Guldanová, 2012) and it is providing the similar results with stable major areas of arable land with considerable changes during intensification and collectivisation. Different ongoing studies in Slovakia (Špulerová et al., 2011; Skokanová et al., 2017) and in Czechia (Kilianová et al., 2017) are copying similar landcover changes and development, especially covering the arable land areas. Currently, this trend in the research area and Slovakia as a country, is turning to land fragmentation and numerous ownerships of the arable and as well non-arable land (Muchová and Lusková, 2017; 
Muchová, 2017). Future management is therefore necessary only with consideration to specifics of landcover changes in this region (Bezák et al., 2017; Klusáček et al., 2018; Jepsen et al., 2015).

\section{Conclusion}

Mire near Pusté Úl'any was originally much larger and probably the biggest mire area in the Danubian lowland during Holocene. The theories of its origin are uncertain. Process of degradation of the mire started by drainage canal building around mideighteenth century, when from the Bratislava County financed a sophisticated drainage system construction to obtain land for pasture and cultivation. Since then, the human interference was huge into this ecosystem. Following peat extraction degraded the local landscape and destroyed the natural biotopes. Besides further research, appropriate protection and monitoring is needed to establish in this area as well as its further management. Some of the anthropogenic biotopes could reverse to a more natural state by this support and the favourable service of this area could be even recreation in the future and not only intensive forest management promoting the invasive species dominance. Currently the grasslands areas are forming in the direct proximity of this water areas as a result of fields desolation, which were cultivated in 1949. Water areas after peat and gravel extraction enables the repeated hydroserie succession forming rich sedge and reed stands that are seasonable biotope for water fowl and other endangered animal species.

Acknowledgements. This research was supported by the Scientific grant Agency of the Ministry of Education, Science and Sport of the Slovak Republic (VEGA 1/0421/16 and VEGA 1/0781/17) and Cultural and Educational Grant Agency of the Slovak Republic under Grant KEGA NO. 032UKF-4/2018.

\section{REFERENCES}

[1] ARCANUM (2004): Az első katonai felmérés. DVD-ROM. - HM hadtörténeti Intézet és Múzeum Térképtára and Arvcanum AdatbázisKft., Budapest. [In Hungarian language].

[2] Bel, M. (1735): Notitia Hungariae Novae Historico Geographica... Tomus Primus P. Straub, Wien. - Ústredná knižnica SAV, Bratislava. [In Latin language].

[3] Bel, M. (1736): Notitia Hungariae Novae Historico Geographica... Tomus Secundus P. Straub, Wien. - Ústredná knižnica SAV, Bratislava. [In Latin language].

[4] Beláková, M. (2014): Hydronymia severnej časti povodia Malého Dunaja. - Pedagogická fakulta, Trnavská Univerzita. Trnava. [In Slovak language].

[5] Bezák, P., Mederly, P., Izakovičová, Z., Špulerová, J., Schleyer, C. (2017): Divergence and conflicts in landscape planning across spatial scales in slovakia: An opportunity for an ecosystem services-based approach? - International Journal of Biodiversity Science, Ecosystem Services and Management 13(2): 119-135. DOI: 10.1080/21513732.2017.1305992.

[6] Bubíková, K., Hrivnák, R., Slezák, M. (2016): Zajímavé nálezy vodních a mokřadných rostlin na území Slovenska [Interesting findings of aquatic and marsh plants from Slovakia]. - Bulletin of the Slovak Botanical Society 38(1): 47-62.

[7] Burgi, M., Bieling, C., von Hackwitz, K., Kizos, T., Lieskovský, J., Martin, M. G., McCarthy, S., Müller, M., Palang, H., Plieninger, T., Printsmann, A. (2017): Processes and driving forces in changing cultural landscapes across Europe. - Landscape Ecology 32(11): 2097-2112. DOI: 10.1007/s10980-017-0513-z. 
[8] Czuczor, G., Fogarasi, J. (1862-1874): A magyar nyelv szótára. 1-6. kötet. - MTA, Pest.

[9] Deak, A. J. (2007): 200 years of habitat changes and landscape use in the South-Tiszavalley, Hungary. - Proceedings and Monographs in Engineering, Water and Earth Sciences: International Confrence Wetlands: Monitoring, Modelling and Management. Wierzba, Poland (22.-25.9.2005).

[10] Guette, A., Godet, L., Robin, M. (2018): Historical anthropization of a wetland: steadz ancroachment by buildings, roads versus back and forth trends in demography. - Applied Geography Journal 92: 41-49.

[11] Hrašna, M., Klukanová, A. (2002): Inžinierskogeologická rajonizácia, mierka 1:500 000. - In: Miklós, L. (ed.) Atlas Krajiny SR. Ministerstvo životného prostredia SR, Bratislava. [In Slovak language].

[12] Hreško, J.; Guldanová, H. (2012): Analýza zmien druhotnej krajinnej štruktúry v oblasti Chráneného vtáčieho územia Úl'anská mokrad'. - Životné Prostredie 46(1): 28-33. [In Slovak language].

[13] Hrnčiarová, T. (2016): Historický obraz Bratislavy a jej okolia na konci 18. storočia s dôrazom na využitie krajiny [Historical image of Bratislava and its surroundings at the end of the 18th century with accent on landuse]. - Geographical Journal 68(1): 3-24.

[14] INGEP (2007): Nové centrum-Pusté Úl'any. - Geofond, Geologický Ústav Dionýza Štúra, Bratislava. [In Slovak language].

[15] Jamrichová, E., Potučková, A., Horsák, M., Hajnalová, M., Barta, P., Tóth, P., Kuneš, P. (2014): Early occurrence of temperate oak-dominated forest in the northern part of the Little Hungarian Plain, SW Slovakia. - The Holocen 1(15): 1-14.

[16] Jamrichová, E., Hédl, R., Kolář, J., Tóth, P., Bobek, P., Hajnalová, M., ... Szabó, P. (2017): Human impact on open temperate woodlands during the middle Holocene in Central Europe. - Review of Palaeobotany and Palynology 245: 55-68. https://doi.org/10.1016/j.revpalbo.2017.06.002.

[17] Jepsen, M. R. et al. (2015): Transitions in European land-management regimes between 1800 and 2010. - Land Use Policy 49: 53-64. DOI: 10.1016/j.landusepol.2015.07.003.

[18] Kilianová, H., Pechanec, V., Brus, J., Kirchner, K., Machar, I. (2017): Analysis of the development of land use in the Morava River floodplain, with special emphasis on the landscape matrix. - Moravian Geographical Reports 25(1): 46-59. DOI: 10.1515/mgr2017-0005.

[19] Klusáček, P., Alexandrescu, F., Osman, R., Malý, J., Kunc, J., Dvořák, P., Frantál, B., Havlíček, M., Krejčí, T., Martinát, S., Skokanová, H., Trojan, J. (2018): Good governance as a strategic choice in brownfield regeneration: Regional dynamics from the Czech Republic. - Land Use Policy 73: 29-39. DOI: 10.1016/j.landusepol.2018.01.007.

[20] Kopecká, M. (2011): Analýza krajinnej pokrývky chráneného vtáčieho územia Úlanská mokrad' z hladiska ekologických nárokov najvýznamnejších druhov. - Geografický Casopis 63(2): 175-188. [In Slovak language].

[21] Kopecká, M. (2013): Agroenvironmentálna podpora v Chránenom vtáčom území Úl'anská mokrad'. - Životné Prostredie 45: 18-183. [In Slovak language].

[22] Krippel, E. (1956): Zpráva o paleobotanickom rozbore rašeliniska Pusté Úl’any. Geofond, Geologický Ústav Dionýza Štúra, Bratislava. [In Slovak language].

[23] Kvaček, Z., Teodoridis, V., Kováčová, M., Schögl, J., Sitár, V. (2014): Lower Miocene plant assemblage with coastal-marsh herbaceaous monocots from Vienna Basin (Slovakia). - Goelogica Carpathica 65(3): 227-239.

[24] Lieskovský, J., Bezák, P., Špulerová, J., Lieskovský, T., Koleda, P., Dobrovodská, M., Burgi, M., Gimmi, U. (2015): The abandonment of traditional agricultural landscape in Slovakia - Analysis of extent and driving forces. - Journal of Rural Studies 37: 75-84. DOI: 10.1016/j.jrurstud.2014.12.007.

[25] Maglay, J. (2005): Čiastková záverečná správa: Geologická mapa regiónu Trnavská pahorkatina v M = 1:50 000. - Štátny geol. Ústav Dyonýza Štúra v Bratislave: Ministerstvo ŽP SR, 2005. 1101. 
[26] Mazúr, E., Lukniš, M. (1978): Regionálne geomorfologické členenie SSR. + 1mapa (1:1000 000). - Geografický Časopis 30(2): 101-125. [In Slovak language].

[27] Muchová, Z. (2017): Assessment of land ownership fragmentation by multiple criteria. Survey Review DOI: 10.1080/00396265.2017.1415663.

[28] Muchová, Z., Jusková, K. (2017): Stakeholders' perception of defragmentation of new plots in a land consolidation project: Given the surprisingly different Slovak and Czech approaches. - Land Use Policy 66: 356-363. DOI: 10.1016/j.landusepol.2017.05.011.

[29] Opršal, Z., Kladivo, P., Machar, I. (2016): The role of selected biophysical factors in long-term land-use change of cultural landscape. - Applied Ecology and Environmental Research 14(2): 23-40. DOI: 10.15666/aeer/1402_023040.

[30] Petr, L., Žáčková, P., Grygar, M. T., Píšková, A., Kř́žek, M., Treml, V. (2013): Š́u, a former late-glacial and Holocene lake at the westernmost margin of the Carpathians. Preslia 2013(85): 239-263.

[31] Pišút, P., Timár, G. (2007): História územia ostrova Kopáč. - Fytoterapia OZ, Bratislava.

[32] Pišút, P., Timár, G., Vidlička, L'. (2010): Súrsky les a Panónsky háj na starších mapách. In: Majzlan, O., Vidlička, L. (eds.) Príroda rezervácie Súr. Ústav Zoológie SAV, Bratislava, pp. 23-66. [In Slovak language].

[33] Purgina, J. (1958): Samuel Mikovíni (1700-1750). Život a dielo. Správa geodézie a kartografie na Slovensku. - Ed. Monumenta Slovaciae Cartographica, Bratislava. [In Slovak language].

[34] Procházka, J., Pišút, P., Jamrichová, E. (2015): Zazemňovanie Gbelčianskej depresie počas holocénu vo svetle analýzy rastlinných makrozvyškov (profil Nová Vieska 2.). Geografický Časopis 67: 85-103. [In Slovak language].

[35] Ružičková, H. et al. (1996): Katalóg biotopov Slovenska. - Ústav Ekológie Lesa SAV, Bratislava. [In Slovak language].

[36] Sedlák, V. (1994): Die Älteste Besiedlung des Komitates Bratislava. - Studia Historica Slovaca 18: 12-128.

[37] Skalos, J., Richter, P, Keken, Z. (2017): Changes and trajectories of wetlands in the lowland landscape of the Czech Republic. - Ecological Engineering Journal 108: 435445 .

[38] Skokanová, H., Havlíček, M., Klusáček, P., Martinát, S. (2017): Five military training areas - five different trajectories of land cover development? Case studies from the Czech Republic. - Geographia Cassoviensis 11(2): 201-213.

[39] Špulerová, J., Dobrovodská, M., Lieskovský, J., Andrej Bača, Halabuk, A., Kohút, F., Mojses, M., Kenderessy, P., Piscová, V., Barančok, P., Gerhátová, K., Krejčí, J., Boltižiar, M. (2011): Inventory and classification of historical structures of the agricultural landscape in Slovakia. - Ekologia Bratislava 30(2): 157-170. DOI: 10.4149/ekol_2011_02_157.

[40] Stanová, V. Valachovič, M. (2002): Katalóg biotopov Slovenska. - Daphne, Bratislava.

[41] Sugita, S. (2007): Theory of quantitative reconstruction of vegetation I: pollen from large sites REVEALS regional vegetation composition. - The Holocene 2(12): 229-241.

[42] Szabó, P., Kuneš, P., Svobodová-Svitavská, H., Švarcová, M. G., Kř́žová, L., Suchánková, S., ... Hédl, R. (2016): Using historical ecology to reassess the conservation status of coniferous forests in Central Europe. - Conservation Biology 31(1): 150-160. https://doi.org/10.1111/cobi.12763.

\section{CITED MAPS AND PLANS}

[1] Vestigium Operationis Astronomico-Geometrica quo Huius ratio et utriusque Harmonia exprimitur. S. Mikovíni. 1732. Size 57 x $65 \mathrm{~cm}$. Moravská zemská knihovna - Moravian Library, Brno (further on: MLB, map collection of B. P. Moll, sign. Moll-0003.255. Available (online) at: http://mapy.mzk.cz/mzk03/001/052/434/2619316509/. 
[2] MAPPA COMITATUS POSONIENSIS accuratione Astronomico - Geometrica concinnata. S. Mikovíni, 1735. MLB, map collection of B. P. Moll, Size 65 x $55 \mathrm{~cm}$, sign. Moll-0003.252. Available (online) at: http://mapy.mzk.cz/mzk03/001/052/430/2619316519/.

[3] Comitatus Posoniensis Germanis Presbvrg dicti, Delineatio geographica, Ex prototypo Micoviniano desumta, et multis in locis, prasertim quoad Hungaricarum \& Slavicarum vocum justiorem orthographiam emendatior reddita. 1757. Bratislava County map, Norimberg, Homann's edition of Mikovíni map. MLB, map collection of B. P. Moll, size 32,5 x $55 \mathrm{~cm}$, sign. Moll-0003.254,2. Available (online) at: http://mapy.mzk.cz/mzk03/001/052/435/2619316512/.

[4] Map of the swamp Csádé in the (historical) Bratislava County. Probably around 1760. National Széchényi Library, Budapest, collection of manuscript maps. Normalised scale 1: 15 000, size 41,4 x 119,8 cm. Sign. TK 1 613. Available at: Hungaricana, maps, https://maps.hungaricana.hu/en/OSZKTerkeptar/1612/?list=eyJxdWVyeSI6ICJjc2FkZSJ 9.

[5] First Military Survey (so called Josephian), 1782-1785, map column 7 (Collone VII.), map layer 6. (sectio VI.), scale 1: 28 800. Arcanum, 2004.

[6] First Military Survey (so called Josephian), 1782-1785, map column 8 (Collone VIII.), map layer 7. (sectio VII.), scale 1: 28 800. Arcanum, 2004.

[7] ATLAS REGNI HUNGARIAE Portatilis... J. M. Korabinský, Vienna, 1804. State Archives in Bratislave, branch Modra.

[8] Second Military Survey (so called Franziscean), map column 26 (Colonne ${ }^{\mathrm{ro}}$ XXVI.), map layer 44 (Section Nro 44.). 1839. Under guidance of captain Schön measured and delineated by G. Nuppenau, described by cadet A. Szuchár. Jankó et al. 2005.

[9] Second Military Survey (tzv. Františkovo), map column 25 (Colonne $\mathrm{N}^{\mathrm{ro}}$ XXV.), map layer 44 (Section $\mathrm{N}^{\mathrm{ro}}$ 44.). Ariund 1839. Under direction of major v. Schönermark measured and delineated by cpt. Kirchmayer v. Würtemberg. Jankó et al. 2005.

[10] Second Military Survey (tzv. Františkovo), map column 25 (Colonne N ${ }^{\text {ro }}$ XXV.), mapová vrstva 43 (Section $\mathrm{N}^{\text {ro }}$ 43.). Okolo 1839. Under direction of major v. Schönermark measured and delineated by oberlt. Sonneschein v. Hohenzollern. Jankó et al. 2005.

[11] (Historical) Bratislava County, 1890-1897. Authors: Vidák István, Sény Géza, Schmodt Szilárd et al. National Archives of Hungary, Budapest, collection of cadastral maps, size 21 x $21 \mathrm{~cm}$ sign. S_78_-_Pozsony_m._-_001-091. Sheets 56, 57, 64, 65. Available at https://maps.hungaricana.hu/en/MOLTerkeptar/14679/?list=eyJxdWVyeSI6ICJwb3pzb25 5IG11Z311In0.

[12] Historical Orthophotomsp of Slovakia, 1949. Publisher: (C) GEODIS SLOVAKIA, s.r.o. a Historické LMS (C) Topografický ústav Banská Bystrica. source: Topographical Institute in Zvolen, Available at http://mapy.tuzvo.sk/HOFM/. 